Egypt. Acad. J. biolog. Sci., 2(2): 115 - 129(2010)

Email: egyptianacademic@yahoo.com

Received: 5/11/2009
C. Physiology \& Molecular Biology

ISSN: 2090-0767

www.eajbs.eg.net

\title{
An Innovative Epigenetic Merge in Treatment of AML Patients Correlates with Better "Molecular and Clinical" Outcomes
}

\author{
Rola M. Ghorab, Pharm D. ${ }^{1}$ and Mohammad F. Kamel, MSc. ${ }^{2}$ \\ ${ }^{1,2}$ Clin. Biochemistry Dep., Alexandria Faculty of Science, Bagdad st., \\ Moharam Bec, P.O. 21547, Alex., Egypt
}

\section{ABSTRACT}

PURPOSE: Epigenetic gene silencing due to promoter hypermethylation \& histone acetylation influence various molecular pathways in leukemogenesity of Acute Myeloid Leukemia (AML). Combined use of DNA methyltransferases \& histone deacetylases inhibitors proved to reverse the methylomic phenotype of myeloid blasts \& improve patient's prognosis. The study recruited 68 Adults patients 45 received novel combination of the HDACi valproic acid +/- the Dnmt1 inhibitor; epigallocatechingallate "EGCG" parallel to standard chemotherapy for 2 successive cycles. RESULTS: We recorded; $37 / 45$ (CR), 7 (PR) \&1 (RF), 60\% MRD elimination. Decreased Dnmt1 \& HDAC1 activities $(\mathrm{p}<0.001)$. Reversed P15 $5^{I N K 4 B}$ gene methylation \& expression states $58 \%,(p<0.02) \&$ decreased levels of VEGF, bfgf, IL-6, NF-KB, TNF, COX-2 \& P65 cytokines levels in a harmonized orchestra $(\mathrm{p}<0.01)$. Survival analyses showed high significant 2 years DFS $(\mathrm{P}<0.01)$. CONCLUSION: The used epi-drug combination distinctively exerted a destructive impact on AML blasts interpreted to tumor regression, better hematological \& clinical response.

Keywords: DFS: disease free survival; Dnmt1 DNA methyltransferases1; HDACi: histone deacetylases inhibitor; MRD: inimal residual disease; VEGF: vascular endothelial growth factor; NF-KB: nuclear factor KB.

\section{INTRODUCTION}

The high relapse rate in Acute Myeloid Leukemia "AML" is a significant clinical problem mainly reflects the survival of residual tumor cells after standard therapy. Simultaneous and rapid epigenetic processes such as DNA methylation and histone posttransductional modifications energize tumor cell to stop or slow its proliferation, differentiation or apoptosis. leading to chemotherapy-resistant phenotyped cells. The epigenetic mechanism of drug resistance gives no exception to abnormal methylation. A theme that is prevalent in the resistant cells and that can be overcome by combining HDAC \& methyltransferases inhibitors to AML standard chemotherapy. As the most frequent alterations found in acute leukemia Promoter silencing by DNA methylation is an established mechanism to inhibit tumor suppressor genes. This inhibition reflects a state of deacetylated chromatin, a conformational change signal that is dictated by HDACs. Working in harmony to alter the transcriptome profile, DNA methylation \& histone acetylation will induce pluripotent resistant phenotype that can be easily reversed targeting these two machineries.

Epigallocatechingallate "EGCG "in green tea" has been proved to inhibit Dnmt1 \& reactivate methylation-silenced genes in cultured cancer cells $[1,2]$ and work with reduced toxicity comparing to nucleoside hypomethylating analogues [3]. As a novel histone acetyltransferase inhibitor "HATi" with global specificity for the majority of HAT enzymes, EGCG showed no activity toward epigenetic enzymes including HDAC and HMTase [4] and it needs to work in concert with a HDACi counterpart to reach the epigenetic 
state of gene re-activation. Clinical implications of EGCG in treatment of cancer cells of varying origins $[5,6,7,8$, $9,10,11]$ would in addition represent a pleiotropic impact in favor of better treatment.

Valproic acid (VPA) is a unique HDAC inhibitor that can enhance (MBD2/dMTase), induce DNA demethylation [12] target a number of non-histone proteins, induce differentiation, cell-cycle arrest [13]\& apoptosis [14]. Clinical efficacy of VPA has been proved in many earlier trials, in MDS, advanced, poor risk, \& refractory AML patients $[15,16]$. A forceful attack to DNA methylation \& histone acetylation would then be expected if these two drugs were combined with the standard AML chemotherapy. Only if they proved to work in concert and without a robust effect, a better patients prognosis would be expected.

Silencing of the tumor suppressor $p 15^{I N K 4 b}$ gene by hypermethylation is a frequent event in various hematological malignancies especially in AML $[17,18]$. It is correlated with Leukemic transformation in nearly all FAB subtypes \& can be detected in bone marrow, peripheral blood cells [19]. Quantifying MRD with estrogen receptor A (ERA) and/or p15 $5^{I N K 4 b}$ methylation proved to account for a high relapse risk and reduced relapse-free survival. Reactivation of $p 15^{I N K 4 b}$ by "EGCG" was prescribed earlier [1]. HDACIs as well, proved to induce reactivation of $p 15^{I N K 4 b}$ through activation of its deacetylated promoter [20] and restraining the formation of a repressive complex [21].

Both EGCG and VPA proved to inhibit $N F-\kappa B$ activation $[22,9]$ which would consequently inhibit downstream proliferative \& angiogenic cytokines as COX2 [23], VEGF [24]\& IL-6 [9] as well as TNF $\alpha$. activation $[25,26]$.

In the present study, we tested this hypothesis that epigenetic treatment with the combination of VPA \& EGCG, parallel to the standard chemotherapy regimen $(3+7)$ would reverse DNA methylation in vivo. Our data have important potential implications on the therapeutic reversal of pathological DNA methylation in acute myeloid leukemia patients.

\section{1-PATIENTS:}

This study recruited 68 unrelated newly diagnosed adults AML patients (27 females, 41 males; mean age, 36.09 years) $\& 23$ healthy subjects for control purposes. All subjects signed a written consent ${ }^{\mathbf{1}^{*}}$. All were admitted \& followed at Alexandria Faculty of Medicine, Department of Internal Medicine and Hematology between March 2006 and July 2008. Patients were classified following FAB classification to (M0, 7 patients; M1, 11; M2, 16; M3, 12; M4, 11; M5, 5; M6, $3 ; \& \mathrm{M} 7,3)$ and were categorized into three treatments arms" CHX $\left(1^{\text {st }}\right)$, VA $\left(2^{\text {nd }}\right), \mathrm{VG}\left(3^{\text {rd }}\right)$; they were all treated within $(3+7)$ protocol. The M3 subtype of AML “ acute promyelocytic leukemia" treated with the drug ATRA (all-trans-retinoic acid) in addition to induction chemotherapy. Both $2^{\text {nd }} \& 3^{\text {rd }}$ arms received $40 \mathrm{mg} / \mathrm{kg} / \mathrm{bwt}$ of VPA tablets per day ${ }^{2^{*}}$. Additional $25 \mathrm{mg} / \mathrm{kg} /$ day of EGCG tablets were given to $3^{\text {rd }}$ arm only. Epidrugs were given starting from day one of chemotherapy to day eight and for two successive THX cycles.

Valproic acid dose used herein was preceded with pilot studies. Doses $10,20,40 \mathrm{mg} / \mathrm{kg}$.bwt were given for two cycles with chemotherapy. LDH \& IL-6 were tested as prognostic indicators. 40 $\mathrm{mg} / \mathrm{kg}$.bwt dose was chosen. As drug level is considered to be a factor favoring toxicity or $\mathrm{G}_{1}$ arrest VPA dose was just within therapeutic levels for epilepsy and thus appears clinically acceptable.

Sequential bone marrow aspirates were obtained when possible. Blood samples were withdrawn before \& after each treatment cycles "for the first two cycle". All samples were handled, and coded. Laboratory tests were done according to the designed protocol and all data were recorded "each in the relevant report. Patients were followed up for 18 after end of their consolidation therapy " each patient received 2 induction \& 3 to 4 consolidation cycles, median of 6 months" 
cases with three time points of follow-up were selected for analysis ${ }^{3^{*}}$

\section{METHODS}

3.1. Preparation of cell pellets: Blood was collected from patient on EDTA and samples were centrifuged at $4^{\circ} \mathrm{C} \& 2000$ r.p.m. for 5 min. plasma was then withdrawn, RBCs were lysed and white blood cell were isolated by centrifugation and preserved in PBS at $\left(-80^{\circ} \mathrm{C}\right)$ until use.

3.2. Preparation of Nuclear Extract \& Quantifying Protein Concentration: Following the method described [27]. Absence of cytosolic LDH was a purityindicator. And, proteins were quantified in $10 \mu 1$ aliquots of nuclear extracts [28]: by using a Bradford assay using the Biorad Dye Reagent Concentrate (BIO-RAD Laborites. Cat. \# 500-0001). BSA as standard. Spectrophotometeric measures were done for standard and samples against blank at O.D 595 on (Ultraspec ${ }^{\circledR}$ 1000 Pharmacia Biotech.U.K). ALL chemicals were purchased from Sigma Aldrich.

3.3. RT-PCR for $p 15^{\text {INK4b }}$ gene: Total RNA was isolated from peripheral blood and from white blood cells pellets using TRIzol ${ }^{\circledR}$ LS reagent (Invitrogen, Paisley, UK. Cat. No. 10296010) as described [29]. Reverse transcription-PCR was done by using the Sigma Enhanced Avian HSRTPCR kit Proceedure was done in One-Step RT-PCR reaction. $0.5 \mu \mathrm{L}$ from each p15 ${ }^{\text {INK4b }}$ primers were purchased from Sigma (sense $\&$ anti-sense 100 pmoles $/ \mu$ l) assayed as described (30) \& amplification was performed using PXE 0.2 thermalcycler (Thermo Electron Co.)

3.4. MS-PCR for $\mathbf{p} 15^{\mathbf{I N K} 4 \mathrm{~b}}$ gene: $5 \mu \mathrm{g}$ of genomic DNA samples were treated with the chemical bisulfite to convert unmethylated cytosines into uracils. Samples were purified using the "EZ Bisulfite DNA Clean-up Kit ${ }^{\mathrm{TM}}$ " from ZYMO Research (Cat.D5025) \& amplified as described [31]. Primers used for p15 unmethylated reaction were: p15 UM were: Sense 5'-TGT GAT GTG TTT GTA TTT TGT GGT T-3' \&Antisense 5'-CCA TAC AAT AAC CAA ACA ACC AA-3'. And p15 M: sense 5'-GCG TTCGTATTTTGC GGT T-3' \&Antisense 5'-CGT ACA ATA ACC GAA CGA CCG
A-3' .GAPDH, 5'CGGAGTCAACGGATT TGGTCGTAT3' \& 5'-AGCCTTCTCCATGGTG G TGAAGAC-3'. PCR conditions were as follows: $95^{\circ} \mathrm{C}$ for $3 \mathrm{~min}$, then 40 cycles at $95^{\circ} \mathrm{C}$ for $40 \mathrm{~s}, 60^{\circ} \mathrm{C}$ for $40 \mathrm{~s}$ and $72^{\circ} \mathrm{C}$ for $40 \mathrm{~s}$, and a final extension of $3 \mathrm{~min}$ at $72^{\circ} \mathrm{C}$. Then $5-6 \%$ PAGE was used for detection as described (30).

3.5. Dnmt1 Activity Assay: This assay is based on methods pre-described [32, 33] using a sensitive, UV-based, enzyme coupled assay. DNA methyltransferase activity was determined in $10 \mu \mathrm{L}$ of nuclear extracts. the nuclear extracts were incubated for 1.5 or $2 \mathrm{hrs}$ at $37^{\circ} \mathrm{C}$ with the Substrate $0.66 \mu \mathrm{M}$ of poly $(\mathrm{dI}-\mathrm{dC}) \cdot \operatorname{poly}(\mathrm{dI}-$ $\mathrm{dC}$ ) and $10 \mu \mathrm{M}$ of S-adenosyl-L-methylmethionine in a total volume of $10 \mu \mathrm{l}$ of a pH 7.4 buffer, containing $20 \mathrm{mM}$ Tris$\mathrm{HCl}, 25 \%$ glycerol (v/v), $10 \mathrm{mM}$ EDTA, $0.2 \mathrm{mM}$ PMSF, $0.02 \%$ DMSO, and $2 \mathrm{mM}$ $\mathrm{MgCl} 2$ as a buffer additive ]. Reaction incubated for $2 \mathrm{hrs}$ The reaction was initiated by the addition of nuclear extracts and stopped by mixing with $300 \mu 1$ of a solution containing $1 \%$ SDS, $0.25 \mathrm{mg} / \mathrm{ml}$ carrier salmon testes DNA and $1 \mathrm{mg} / \mathrm{ml}$ proteinase $\mathrm{K} \&$ chilling in ice. $6.5 \mu \mathrm{l}$ of solution (a) containing ADA (15U/1mg; Worthington Biochem.) \& S.adenosyl-Lhomosycteine nucleosidase (1U) were buffered in $173.5 \mu \mathrm{l}$ solution (b) [ $50 \%$ glycrol (v/v), $0.01 \mathrm{mM} \mathrm{KH2PO4} \mathrm{PH} 6.0$ ]. The mixture is pre warmed to R.T., and $180 \mu \mathrm{l}$ of that mix is added per well, in a final volume of $200 \mu \mathrm{l}$ per well. We immediately made wells to zero point and began to measure absorbance at $510 \mathrm{~nm}$. For the background control, aliquots of 10 $\mu l$ acceptor substrate were added to aliquot $10 \mu \mathrm{l}$ SAM MTase Assay Buffer into each background control well. The background control was subtracted from samples and then a curve of protein content against absorbance was plotted representing rate of the enzyme activity. Except of ADA all other chemicals were purchased from Sigma.

3.6. HDAC Activity Assay: This assay was performed using Biomol HDAC Colorimetric Activity/Inhibition Assay Drug Discovery Kit (Biomol ${ }^{\circledR}$ International LP. Cat. No. AK-501) \& according to the manufacturer' instruction. 
The HDAC reaction was initiated by addition of diluted Color de Lys TM substrate and stopped after appropriate time by addition of diluted Color de Lys ${ }^{\mathrm{TM}}$ developer (containing Trichostatin A). Absorbance was read at $405 \mathrm{~nm}$. A curve of protein content against absorbance was plotted representing rate of the enzyme activity. HDAC activity was signified as a function of O.D. 405.

3.7. Determination of IL-6 in patients' sera: This determination was set using BioLegend's ELISA MAX ${ }^{\mathrm{TM}}$ Set Standard Human IL-6 kit (Cat. 430502) \& according to the manufacturer' instruction. Tween-20 was purchased from Sigma (Cat. \# P-7949) TMB Substrate \& Assay Diluent were purchased from BioLegend's Cat. No. 421101, \& 421201 respectively. The sensitivity of the kit was $1 \mathrm{pg} / \mathrm{ml}$ of IL-6. Absorbance was read at $450 \mathrm{~nm}$ with (BioTek Elx-800, Germany micro-plate reader), and concentration of IL-6 in sera was determined in $\mathrm{pg} / \mathrm{ml}$ using standard curve.

3.8. Determination of TNF- $\alpha$ in patients' sera: This quantifying was done using Human TNF- $\alpha$ ELISA Development Kit (Peprotech, cat \# 900-K25). BSA, \& ABTS Liquid Substrate Solution were purchased from Sigma Cat \# A-7030, \& A3219); Where Dulbecco's PBS [10x] was obtained from (Gibco BRL Cat. \# 14200-075). Absorbance was read at 405 $\mathrm{nm}$ with wavelength correction set at 650 $\mathrm{nm}$. The sensitivity of the kit was within the range of $32-2000 \mathrm{pg} / \mathrm{ml}$.

3.10. Determination of VEGF\& bFGF: These assays were set as described [34] using Human EG-VEGF ELISA development Kit (Peprotech, Cat. \# 900 K433) for the quantitative measurement of natural $h$ EG-VEGF in a sandwich ELISA format. The sensitivity of the kit was within the range of $16-1000 \mathrm{pg} / \mathrm{ml}$. Absorbance was read using the former BioTek ELISA plate reader BioTek at 405 $\mathrm{nm}$ with $\lambda$ correction at $650 \mathrm{~nm}$. bFGF assay was performed using quantitative sandwich enzyme immunoassay technique. The Human FGF basic EIA Kit from ALPCO Diagnostics Cat. No. 45-FGFHUE01 was used for the assay. Absorbance was read at $450 \mathrm{~nm}$ within against blank. FGF-b concentrations for unknown samples and controls were extracted from the standard curve $\&$ values obtained were multiplied by 2 to correct for the 1:2 dilution.

3.11. Estimation of $N F-\kappa B$ in Nuclear Extract: Procedure was performed as described [35] for the estimation of the activated NF- $\mathrm{KB}$ in nuclear extract. The probe 2 pmole of $22 \mathrm{bp}$ of the sequence [5'-AGTT GAG GGG ACT TTC CCA GGC-3' ] was manufactured by Linilab., Cairo, Egypt. And the following chemicals were purchased: Streptavidin-coated plate (Sigma Cat \# M5432 Sigma Screen), Rabbit Anti-NF- $\kappa \mathrm{B}$ antibody (BioLegend Cat \# 622601), Peroxidase-Conjugated goat anti-rabbit IgG (Cayman Chem. Cat \# 10003401), \& TMB substrate (BioLegend B104903). The developed yellow color was read using BioTek ELISA plate reader at $450 \mathrm{~nm}$ with a reference wavelength $(\lambda)$ $655 \mathrm{~nm}$. The

Intensity of the colored product was directly proportional to the concentration of the activated NF- $\mathrm{KB}$ in the original sample.

3.12. Western blotting for COX2 and p65: COX2 and p65 immunoblots were performed on prepared nuclear extract. Following method pre-described [36]. Protein were quantified in nuclear extracts and assayed in $20 \mu 1$ protein lysates. Antibodies for COX2, P65, \& lamin B were purchased from (Santa Cruz Biotechnology Inc. Cat. \# sc-1745, 1:300, sc-109, $\quad 1: 300, \quad \& s c-6217,1: 300$ respectively). DTT, Bromophenol blue.\& TEMED from (Sigma Cat \# D 9760, $114391 \&$ T9281 respectively),HRPconjugated secondary $\mathrm{Ab}$ from abcam (1:1000; ab 6721. Abcam U.S.A.). Ab labeling was visualized by Chemiluminescence Reagent Plus (PerkinElmer Life Science's Cat. \# NEL103), and membrane was exposed to Kodak XAR-5 film (Eastman Kodak Co., Rochester, N.Y., USA).

\section{RESULTS AND DISSCUSSION}

Valproic acid (VPA) \& green tea extract have been used as well-tolerated drugs with various therapeutic effects [514]. In this study we combined these two epidrugs as an epigenetic "parallel treatment" protocol with the standard 
AML chemotherapy (3+7). Peripheral blood samples were collected \& tested for effect on the DNA methyltransferase1 "Dnmt1" activity. Methylation activity assay was performed as described previously (Section 3.5) to determine the relative levels of activity following our treatment. Lanes (1) in Fig. (1a) shows result obtained from control patients' samples. Lanes (2, 4 \& 6) represents means levels of enzyme activity before treatment in all groups. While lanes (3, 5 \& 7) represents activity after 2 treatment cycles. Results showed an approximately one third reduction in activity (34\%) in lane (7) represents VG group ( $3^{\text {rd }}$ arm of treatment, received VPA + EGCG in addition to chemotherapy) comparing to a minimal \& imperceptible decrease by $7 \%$ in lane (5) represents VA group; $\left(2^{\text {nd }}\right.$ arm of treatment, received VPA in addition to chemotherapy) \& a noticeable increase in $1^{\text {st }}$ arm category who received chemotherapy alone by $16 \%$; lane (3).

Study recorded "for the first time to our knowledge" a slight decrease in Dnmt 1 activity in category of $2^{\text {nd }}$ treatment arm due to VPA treatment which implies that Dnmt1 gene is possibly regulated by histone acetylation mechanism bearing results recorded earlier (37). Yet this effect was absent in samples from patients treated with doses $<40 \mathrm{mg} / \mathrm{kg} / \mathrm{BWT}$ "pilot study". A possible mechanism discussed earlier of docking of EGCG in the catalytic pocket of the enzyme in vitro (1) may stood for inhibition of the enzyme in vivo as in $3^{\text {rd }}$ arm (VG group) as well.

The effect of inhibitors represented in Figure (1b) shows The Eadie-Hofstee plots for the inhibition of "Dnmt1"\& determining the Michaelis Constant $\mathrm{Km}$ and the Limiting Velocity Vmax after 2 cycles of THX. $3^{\text {rd }}$ arm gave the greatest inhibition effect on the enzyme reducing Vmax to $0.42 \mathrm{pmol}$ $/ \mathrm{min} / \mathrm{mg}$ instead of $0.93 \mathrm{pmol} / \mathrm{min} / \mathrm{mg}$ in $1^{\text {st }}$ arm.

DNA methylation and histone modifications, effect on HDAC activity was measured. Figure (2) shows a marked decrease in activity in both $2^{\text {nd }} \& 3^{\text {rd }}$ arms of treatment $(\approx 60 \%)$ with $\mathrm{P}<0.0001$, suggesting that a mechanism of epigenetic gene control alterations by EGCG might be exerted corresponding to almost equal rise in activity in $1^{\text {st }}$ arm.

To determine if there was a reactivation of silenced genes in Leukemic Blasts, methylation analysis of $\mathrm{p} 15^{\mathrm{INK} 4 \mathrm{~b}}$ gene was performed. Methylation analyses for 15 gene in the recruited subjects were done at two points before \& after end of treatment (A \& B), Fig. (3a) represents MS-PCR for p15gene. Results showed: A decrease in methylation level of $P 15^{I N K 4 b}$ in $3^{\text {rd }}$ arm (lanes $6,7,8$ ) more that that recorded in $2^{\text {nd }}$ arm (lanes $3,4,5$ ) while no difference at all was recorded in $1^{\text {st }}$ arm group received CHX alone-(lanes 1, 2). Hypomethylation of the $P 15^{I N K 4 b}$ gene was accordant to retain the gene expression in $2^{\text {nd }} \& 3^{\text {rd }}$ arms as seen in fig. ( $\left.3 \mathrm{~b}\right)$. Figures (3c) \& (3d) shows the rest MS-PCR results for $10 \& 9$ cases of both $2^{\text {nd }} \& 3^{\text {rd }}$ arms respectively $(\mathrm{P}<0.02)$. Table (1) shows number of cases recorded before treatment with increased $P 15$ methylation \& reduced $P 15$ expression in treated groups and the change in these two parameters post treatment. The pattern of Dnmt1 activity inhibition underlined the change in $P 15^{I N K 4 b}$ methylation status in each case "results not shown".

Table 1: Methylation analysis data for all treated groups. $\mathrm{X}_{1}$ \& $\mathrm{Y} 1$ :no of patients with reduced /absent P15 mRNA expression \& P 15 methylation respectively at diagnosis. $\mathrm{X}_{2} \& \mathrm{Y} 2$ : no of patient with increased mRNA expression \& P 15 methylation respectively at end of treatment. $(\mathrm{R} \%)$ : percent increase in P15 mRNA expression. (M\%): percent decrease in $\mathrm{P} 15$ methylation. : CHX: chemotherapy; VA: group treated with chemotherapy + valproic acid; VG: group treated with chemotherapy + valproic + green tea.

Methylation analysis data for all treated groups

\begin{tabular}{|c|c|c|c|c|}
\hline & $\mathrm{X} 1$ & $\begin{array}{c}\mathrm{X}_{2}(\mathrm{R} \%) \text { Post } \\
\text { THX }\end{array}$ & Y1 & $\begin{array}{l}\text { Y2 (M\%) } \\
\text { Post THX }\end{array}$ \\
\hline CHX & $18 / 23$ & No change & $12 / 18$ & No change \\
\hline VA & $18 / 23$ & $\begin{array}{c}10(55 \%) \\
4(25 \%)\end{array}$ & $16 / 18$ & $\begin{array}{c}5(13 \%), 1 \\
(25 \%) 2 \\
(52 \%)\end{array}$ \\
\hline VG & $16 / 22$ & $\begin{array}{c}11(80 \%), \\
5(33 \%)\end{array}$ & $15 / 16$ & $\begin{array}{l}7(80 \%), \\
3(40 \%) \\
3(60 \%), \\
2(33 \%)\end{array}$ \\
\hline
\end{tabular}

To determine whether treatment down regulated proliferation of leukemia cells we measured IL-6 level. Results indicated that despite the different pattern 
of IL-6 in each FAB subtype the overall result was the down-regulation of IL-6. The change in IL-6 level was regarded as separate category per subtype. IL-6 mean values variation in all treated patients represented in fig. (4a) shows tendency toward applying the proposed regimen with $p \leq 0.006$ in $2^{\text {nd }}$ arm $\& p \leq 0.003$ in $3^{\text {rd }}$ arm. This decrease in IL-6 came accordant to patient prognosis and lower levels were associated with lower percentage of blasts in the peripheral blood \& with decrease in the methyltransferase activity" not shown". Results supported evidence of IL-6 cytokine-mediated alteration of methyltransferase gene expression $(38,39,40)$.

$\mathrm{TNF} \alpha$ production was proved to accompany myeloid differentiation (41) and vascularity in the bone marrow as well as increased levels of various angiogenic factors including vascular endothelial growth factor (VEGF), basic fibroblast growth factor (bFGF) (42). Fig. (4b) shows collective results of mean values of $\mathrm{TNF} \alpha$, VEGF \& bFGF in $(\mathrm{pg} / \mathrm{ml})$ after each treatment cycle. Upon detecting TNF- $\alpha$ level represented the highest decrement percent reaching $57 \%$ after 2 nd cycles in $3^{\text {rd }}$ arm that received VPA+ green tea extract with chemotherapy. While in VA group the percent was $44 \%$, $\&$ only $29 \%$ in CHX. The output of Angiogenesis- related cytokines in $2^{\text {nd }} \&$ $3^{\text {rd }}$ arm was reduced by $60 \% \& 69 \%$ respectively in case of VEGF, comparing to $37 \%$ in CHX group. While bFGF reduced by $48 \%$ \& $39 \%$ respectively comparing to $32 \%$ in $\mathrm{CHX}$ group. The marked level of VEGF decrease rather than bFGF supposed to be due the relationship between VEGF secretion and VPA (43) which was lesser in case of EGCG integration.

Investigating the proliferation suppressing potential of the applied regimen, we tested samples for NF- $\kappa \mathrm{B}$ inhibition. Figure (5a): represent results of inhibition of NF- $\mathrm{KB}$ in recruited subjects, showing at $p=0.01$, there was no significant difference in group received the standard chemotherapy. In $2^{\text {nd }} \& 3^{\text {rd }}$ arms, we recorded $44 \% \& 53 \%$ decrease in NF$\kappa B$ level, respectively. Suppression of NF$\kappa \mathrm{B}$ limits the proliferation of cancer cells
$\&$ has potential therapeutic consequences. Down regulation of $\mathrm{NF}-\kappa \mathrm{B}$, would then increase the cellular susceptibility to TNFinduced apoptosis. Western Blot analysis for the change of COX2 \& P65 protein levels showed reduction of both COX-2 \& P65 in $2^{\text {nd }}$ arm in $18 / 23 \& 12 / 23$ cases respectively $(\mathrm{p}<0.001)$, while in $3^{\text {rd }}$ arm reduction was recorded in 21/22 \& 17/22 cases respectively. There was no significant change in $1^{\text {st }}$ arm. Figure (5b) represents results of 5 cases in $2^{\text {nd }} \& 3^{\text {rd }}$ arms before (A) \& at the end of treatment (B). Reduction of COX-2 may be due to bilateral inhibition that might be triggered by both HDACi blocking to TNF- $\alpha$ activation (44) and green tea catechins suppressive effect on NF- $\kappa \mathrm{B}$ (45) Reduction of the P65 in $2^{\text {nd }}$ arm, would further be associated with sequential $\mathrm{I} \kappa \mathrm{B}$ kinase suppression \& suppression of NF$\kappa \mathrm{B}$ trans-activation, consequently $\mathrm{COX} 2$ inhibition forcing cells to commend apoptosis. An effect that possibly increased in $3^{\text {rd }}$ arm upon combining green tea. (46), Clinical data showed that this impact on methylation level had a desirable outcome in patients prognosis, the majority in epigenetically treated groups show rehearse of complete remission with one refractory case in $2^{\text {nd }}$ arm and no deaths, third arm actually showed no RF cases (Table 2). Hematological data ${ }^{4^{*}}$ as represented in fig. (6) "upper left " shows a notable decrease in minimal residual disease (MRD) in these groups $(\mathrm{MRD} \leq 1 \%, \mathrm{p}=0.004$; $0.0036)$ in $2^{\text {nd }} \& 3$ rd arms respectively with complete elimination of MRD (in 17 / 37 CR patients). Samples with reduced/ negative reversal of p15 methylation mirrored clinical data for patients with PR:RF "the majority were in $1^{\text {st }}$ arm of treatment.

According to MRD status during/after therapy, two groups of patients. In $7 / 45 \mathrm{PR}$ cases in both epigenetically treated arms who had MRD levels of less than $10 \%$ in relation to all time points tested after therapy, 6 experienced relapse before 15 months of follow up in $2^{\text {nd }}$ arm $\& 1$ in $3^{\text {rd }}$ arm. Other who experienced relapse came after 15 month, with median remission duration of 
$17 \& 24$ months in $2^{\text {nd }} \& 3$ rd arms respectively.

Table 2: Patient prognostic indices/ FAB Subtype in all treated groups. Abbreviations: CHX: chemotherapy; VA: group treated with chemotherapy + valproic acid; VG: group treated with chemotherapy + valproic + green tea, (m0-m7): FAB subtypes of AML, CR: complete remission; PR, partial remission; RA, refractory anemia;

\begin{tabular}{|c|c|c|c|c|}
\hline Groups & CR & PR & $\mathrm{RF}$ & Failed \\
\hline CHX & $\begin{array}{l}\text { 1(M1), 3(M2), } \\
\text { 2(M3), 2(M4), }\end{array}$ & $\begin{array}{l}\text { (M2), } \\
\text { 2(M3), } \\
\text { 3(M4). }\end{array}$ & $\begin{array}{c}\text { 2(M1), } \\
\text { 2(M2), } \\
\text { 1(M5).1(M6) }\end{array}$ & $\begin{array}{l}\text { 1(M0) } \\
\text { 1(M7) }\end{array}$ \\
\hline VA & $\begin{array}{l}\text { 2(M0), 2(M1), } \\
\text { 5(M2), 6(M3), } \\
\text { 2(M4), 1(M5) }\end{array}$ & $\begin{array}{c}\text { 2(M0),1 } \\
\text { (M1), 1(M4) }\end{array}$ & 1(M7) & \\
\hline VG & $\begin{array}{c}\text { 2(M0), 3(M1), } \\
4(\mathrm{M} 2), 3(\mathrm{M} 3), \\
4(\mathrm{M} 4), 2(\mathrm{M} 5), \\
1(\mathrm{M} 7)\end{array}$ & 1(M5), 2(M6) & & \\
\hline
\end{tabular}

Survival analyses (fig. 6) provided evidences on rehearse of remission endpoint \& decreased risk of relapse. Progress-Free Survival (PFS) curve "upper right" shows that third arm of treatment "VG group" had the fastest \& highest ratio of complete remission between groups. Disease-Free Survival (DFS) curve "lower right" showed that the fastest relapse was in CHX group, "that relapse delay came consistent with both drawbacks in p15 $5^{\mathrm{INK} 4 \mathrm{~b}}$ methylation and MRD".
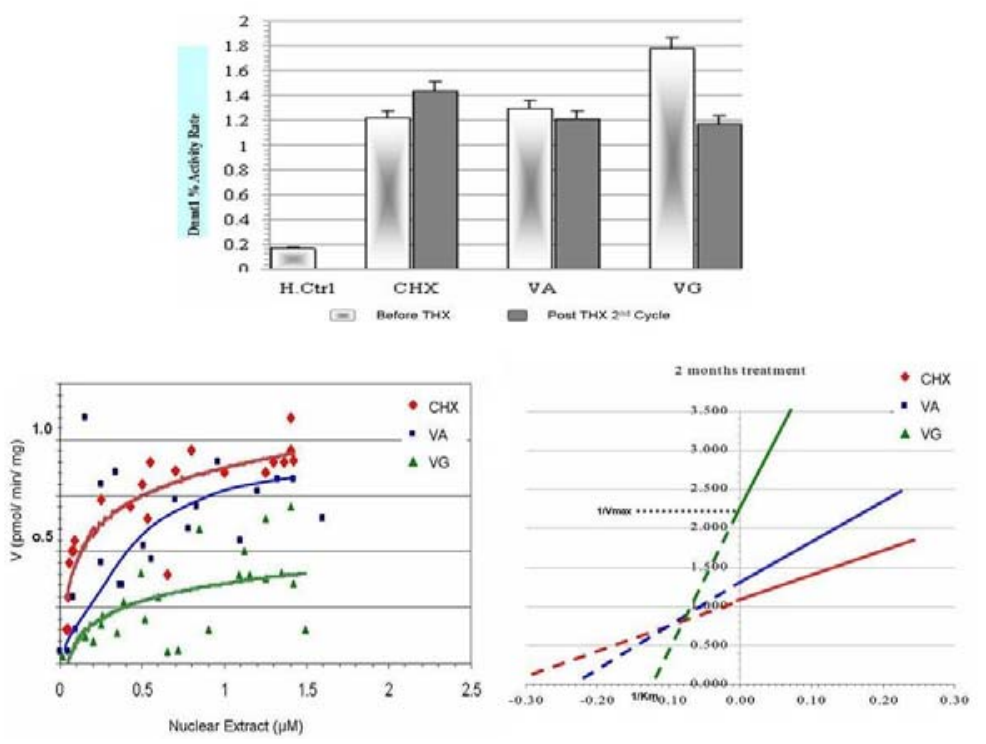

Fig. (1): Inhibition of 5-cytosine DNA methyltransferase "Dnmt1" activity. (a) Inhibition of Dnmt1 activity rate in recruited subjects, represented as mean values before \& at the end of treatment. Abbreviations: H.Ctrl: healthy control; CHX: chemotherapy; VA: group treated with chemotherapy + valproic acid; VG: group treated with chemotherapy + valproic + green tea.. The assay was done as prescribed in methods. Results are mean of 2 determinations, $(\mathrm{P} \leq 0.01)$. (b) Eadie-Hofstee plots for the inhibition of "Dnmt1". Each data point is the mean of duplicate determinations. At 95\% confidence interval, in CHX group $\mathrm{Km}=0.82+0.006 \mu \mathrm{M} \&$ Vmax $=$ $0.93 \mathrm{pmol} / \mathrm{min} / \mathrm{mg}$. In VA group $\mathrm{Km}=0.43+0.008 \mu \mathrm{M} \&$ Vmax $=0.78 \mathrm{pmol} / \mathrm{min} / \mathrm{mg}$. In VG group $\mathrm{Km}=0.33+0.008 \mu \mathrm{M} \& \operatorname{Vmax}=0.42 \mathrm{pmol} / \mathrm{min} / \mathrm{mg}$. Data were analyzed by Two-way ANOVA (V. 8.0 SR2, 2008). 


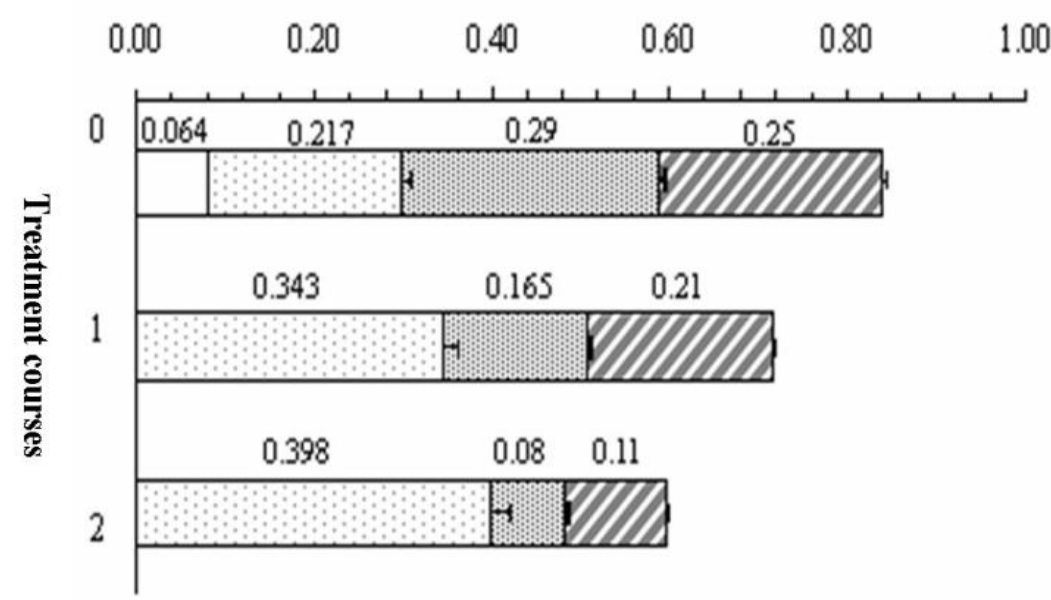

\section{口H.Ctrl QCHX @ VA $\triangle$ VG}

Fig. (2): Inhibition of HDAC activity in recruited subjects. Abbreviations: $(0,1, \& 2)$ : Time courses of treatment; H.Ctrl: healthy control; CHX: chemotherapy; VA: group treated with chemotherapy + valproic acid; VG: group treated with chemotherapy + valproic + green tea; significance between 0,2 cycles $(p \leq 0.0001)$ in VA \& VG groups. Each data point represents the mean SD of 3 determinations. mean values cumulative bars shows HDAC activity is more reduced when EGCG in green tea extract was added.
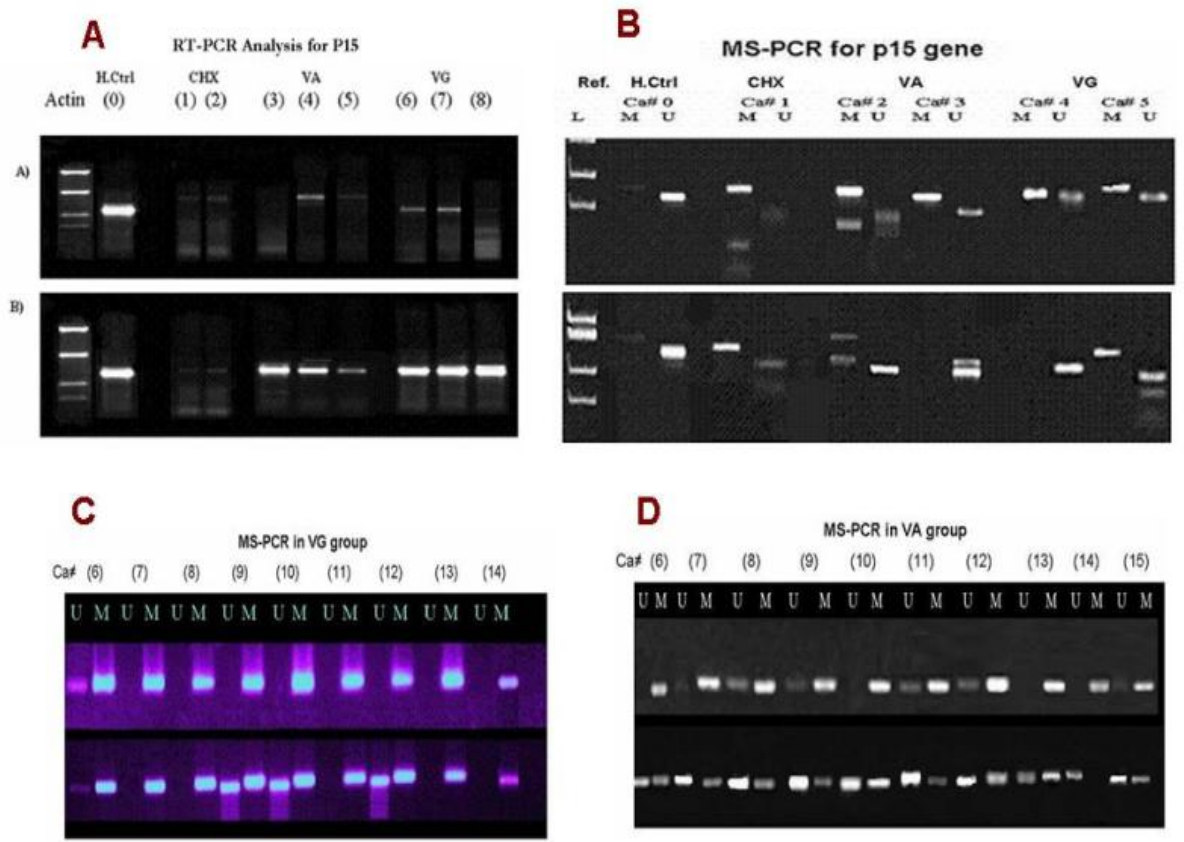

U: unmethylated; M:methylated Upper panels: Before treatment; Lower panels: Post treatment

Fig. (3): Alterations of methylation status and mRNA expression levels of p15INK4b gene in AML patients. For all divisions "upper panels" represent before treatment \& "bottom panels" represent end of treatment. (a) Shows the mRNA expression levels in 9 cases of recruited subjects. $4 \mu \mathrm{g}$ of m.RNA was used in a reverse transcription reaction as per protocol with $\beta$-actin as internal control. Products were electrophoresed on $3 \%$ agarose gel, stained with EtBr. (0- 8) cases number. (b) (c) \& (d): Shows methylation change in AML patients after epigenetic treatment. $5 \mu 1$ of chemically modified genomic DNA was used in a methylation specific PCR reaction as per protocol using GADP as control \& electrophoresed using PAGE. H.Ctrl: healthy control; CHX: chemotherapy; VA: group treated with chemotherapy + valproic acid; VG: group treated with chemotherapy + valproic + green tea. methylated (M), unmethylated bands (U). [Ca\# ] case number; (0) H.ctrl; (1) CHX gp; (2,3) VA gp; $(4,5)$ VG gp. No change was recorded in H.Ctrl (ca \# 0). 


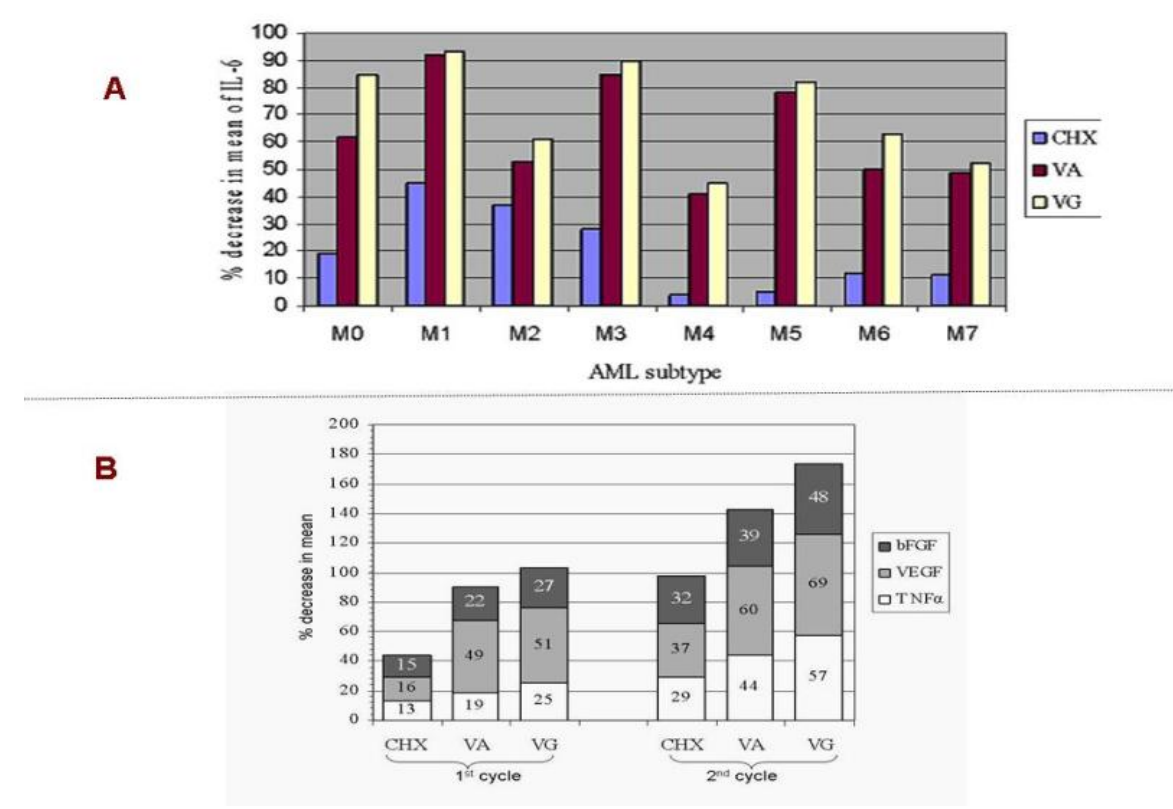

Fig. 4: Detection of cytokines inhibition in epigenetically-treated AML patients. IL-6, TNF $\alpha$, VEGF \& bFGF activities were measured as described in the text. Activity of each was taken as $100 \%$. (a): IL- 6 mean values variation in all treated patients. Mean values ranged between (439.0 - 764.0) in M0; (97.5 - 694.6) in M1; $(3296.0$ - 697.0) in M2; $(69.0$ - 477.0) in M3; (33.2 - 53.0) in M4; (2050.0 - 3116.0) in M5; $(61.0$ - 2504.0) in M6; $(42.6$ - 63.0) in M7. Decrease in mean within the same FAB subtype in each treatment group was in the order $\mathrm{CHX}<\mathrm{VA}<\mathrm{VG}$ ( $\mathrm{p} \leq 0.006$ in $2^{\text {nd }}$ arm $\& \mathrm{p} \leq 0.003$ in $3^{\text {rd }}$ arm). (b): Collective results of mean values of TNF $\alpha$, VEGF \& bFGF $(\mathrm{pg} / \mathrm{ml})$ after each treatment cycle in all treated patients. Each data point represents the mean SD of 3 determinations, $(\mathrm{P} \leq 0.01)$. Abbreviations: (M0M7): FAB subtype; H.Ctrl: healthy control; CHX: chemotherapy; VA: group treated with chemotherapy + valproic acid; VG: group treated with chemotherapy + valproic + green tea. Results are expressed as means \pm SEM. Each data point represents the mean SD of 3 determinations.

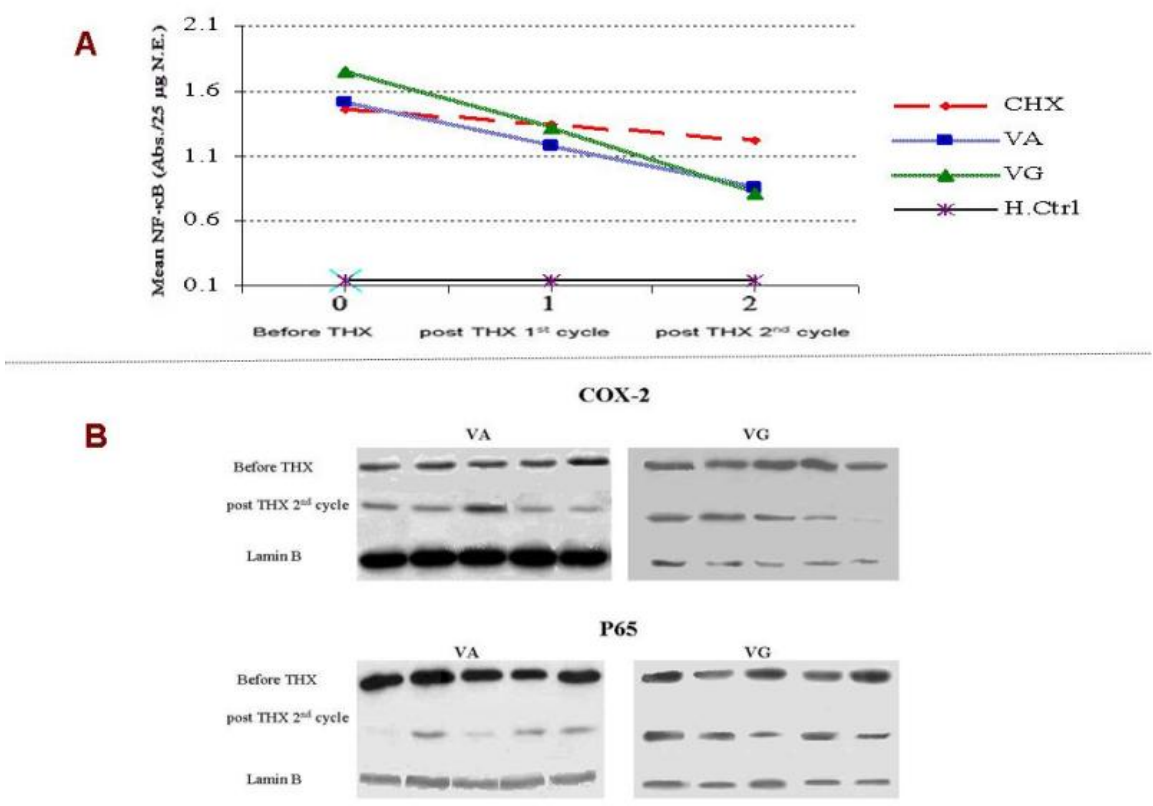

Fig. 5: (a): Mean values of inhibition of NF- $\kappa B$ in all recruited subjects before $(0) \&$ after $(1,2)$ treatment cycles. H.Ctrl: healthy control; CHX: chemotherapy; VA: group treated with chemotherapy + valproic acid; VG: group treated with chemotherapy + valproic + green tea. (b): Western Blot analysis for the change of COX2 \& P65 protein levels represents results of 5 cases in $2^{\text {nd }} \& 3^{\text {rd }}$ arms before (A) \& at the end of treatment (B). Protein were quantified in nuclear extracts and assayed in $20 \mu 1$ protein lysates as mentioned in methods and compared to Lamin $\mathrm{B}(\mathrm{P} \leq 0.008)$. 

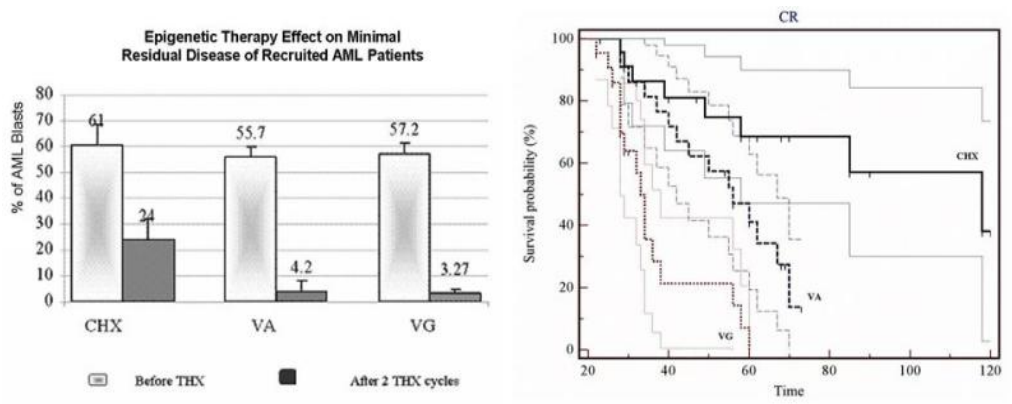

Cox proportional-hazard regression Curve
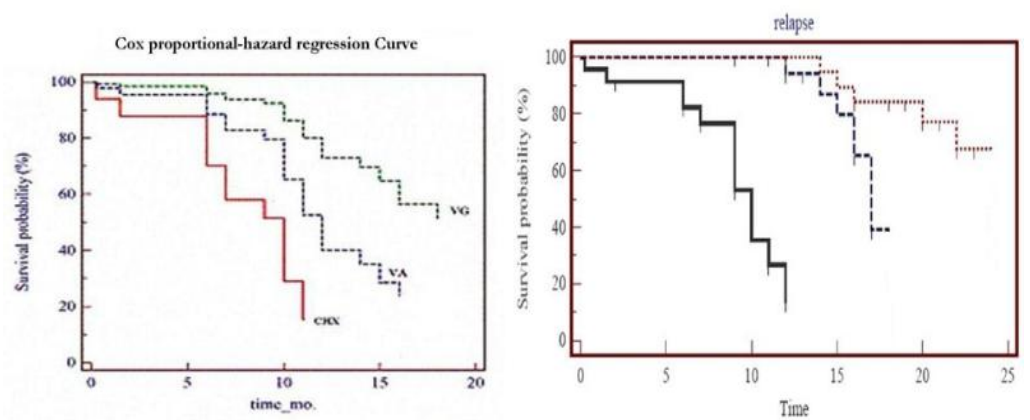

Fig. (6): Clinical \& survival Data: "upper left” represents Epigenetic Therapy Effect on Minimal Residual Disease "MRD" of Recruited AML Patients. MRD in all recruited subjects before (0) \& after 2 treatment cycles are expressed as percents of means \pm SEM. Each data point represents the mean SD of 3 determinations. (MRD $\leq 1 \%, \mathrm{p}=0.004 ; 0.0036)$ in $2^{\text {nd }} \& 3^{\text {rd }}$ arms respectively. In $18 / 23 \mathrm{CR}$ cases in $2^{\text {nd }}$ arm, 6 showed 0 blasts in bone marrow after $1^{\text {st }}$ cycle; situation didn't change after $2^{\text {nd }}$ cycle. One more case progressed to " 0 blast point" after $2^{\text {nd }}$ cycle. In $19 / 22$ cases in $3 \mathrm{r}^{\mathrm{d}}$ arm, 11 showed 0 blasts in bone marrow after $2^{\text {nd }}$ cycle. 8 cases came after $2^{\text {nd }}$ cycle. In 7/45 PR cases in both epigenetically treated arms, number of blasts $\leq 6 \%$. “upper right”: Kaplan Meier's Progress-Free Survival (PFS) curve shows median times to reach complete remission $\left(45,65,110\right.$ days) in $1^{\text {st }}, 2^{\text {nd }}, \& 3^{\text {rd }}$ arms of treatment respectively. Third arm of treatment "VG group" showed the fastest \& highest ratio of complete remission between groups. "Lower right": Kaplan Meier's Disease-Free Survival (DFS) curve shows $1^{\text {st }}$ arm of treatment with significantly decreased relapse-free survival (mean, 285 days; $\left.\mathrm{P}=0.06\right) \&$ high levels of p15 methylation, while in $2^{\text {nd }} \& 3^{\text {rd }}$ arms, relapse delayed with (mean, 510 days, $\mathrm{P}=$ 0.005 )\& (mean, 720 days; $P=0.002$ ) respectively. With $95 \%$ confidence, risk of relapse is approximately 1.8 \& 2.5 times in CHX group than the risk in VA\& VG groups. The majority of patients with high levels of $\mathrm{p} 15^{\mathrm{INK} 4 \mathrm{~B}}$ methylation in remission have relapsed, whereas patients with low levels of methylation have not, the majority was in $2^{\text {nd }} \& 3^{\text {rd }}$ arm groups (DFS $=24$ months chi-square value of 15.35 and $\mathrm{p}<0.001)$. "Lower left": Cox-regression Curve for covariates [LDH, NF- $\kappa B$, VEGF, TNF $\alpha$ levels and MRD] showed a "within group expo". Cumulative hazard factor equals 0.3446 upon increase of the studied variables. All variables used were found to significantly contribute to the prediction of time, and were all included in the model. A HR $<1(\operatorname{Exp}(b)=0.3446$ with increasing $95 \%$ CI of $\operatorname{Exp}(b)$ $=0.1608$ to 0.7384 means that our treated VA \& VG groups of interest when compared to the reference CHX group are less likely have a shorter time to end event. Abbreviations: CHX: chemotherapy; VA: group treated with chemotherapy + valproic acid; VG: group treated with chemotherapy + valproic + green tea. 
The majority of patients with high levels of p15INK4B methylation in $1^{\mathrm{st}}$ arm of treatment in remission $(12 / 18$, $67 \%$ ) experienced shorter time to relapse (mean 285 days) with statistical significance $(\mathrm{P}=0.06)$, whereas patients with PR in $2^{\text {nd }}$ arm "all had a reversed levels of methylation" had relapsed later (mean, 510 days, $\mathrm{P}=0.005$ ). A notable significant difference in relapse-free survival was observed in $3^{\text {rd }}$ arm (mean, 720 days; $\mathrm{P}=0.002$ ). Both arms when compared to $\mathrm{CHX}$ group are less likely have a shorter time to end event which is relapse. Cox-regression Curve for covariates [LDH, NF- $\kappa \mathrm{B}, \mathrm{VEGF}, \mathrm{TNF} \alpha$ levels and MRD] showed $(\mathrm{P}=0.00641$; HR $<1(\operatorname{Exp}(b)=0.3446$ with increasing $95 \% \mathrm{CI}$ of $\operatorname{Exp}(\mathrm{b})=0.1608$ to 0.7384 ) With $95 \%$ confidence, risk of relapse is approximately $1.8,2.5$ times in $\mathrm{CHX}$ group than the risk in VA\& VG groups respectively. For the considered regression coefficients: $\quad \mathrm{p}<.01$, with increasing 95\% CI of Exp (b) values were in the positive direction.

Putting forward these results, we bring to a close that targeting the DNA methyltransferase1 \& histone deacetylation potential using both Valproic acid \& Epigallocatechingallate " together as in the prescribed regimen" had reactivated $\&$ reversed the methylation of $p 15^{I N K 4 b}$ gene in vivo of AML patients, retained TGF- $\beta$ regulatory signal. We suppose that VPA \& EGCG managed together to inhibit methylation directly via inhibiting Dnmt1 \& HDAC and indirectly by down-regulation of IL-6 $(9,22,38)$. Also down-regulation of growth factors including IL-6 \& TNF $\alpha$ which held back proliferation of AML blasts. Considering the fact that cells arrested in $\mathrm{G}_{1}$ progress toward differentiation, and finally to apoptosis (47), the effect of TNF- $\alpha$ on downstream events including NF- $\kappa \mathrm{B}$ cytoplasmic translocation, shared to decrease expression of target genes as $\mathrm{COX} 2$ "bearing in mind the direct effect of VPA \& EGCG on COX-2". Reduction of COX-2 mRNA \& protein shared to downregulate the release of VEGF, drew back angiogenic potential and progression of cells from G0 to G1 phase which could free the seizing of apoptotic potential within the tumor niche, abate proliferation \& angiogenic switches to the malignant epigene.

In our study, we show that the HDAC inhibitor VPA reversed p15 methylation, induced apoptosis, promoted differentiation and improved patient prognosis, all at the same dose (40 $\mathrm{mg} / \mathrm{kg}$.bwt) making a dose-dependent effect unlikely. Yet, the net effect was markedly improved when EGCG in green tea extract was introduced, a factor that reflected patients prognostic dissimilarities between the two arms.

Toxicity grading and evaluation of the applied regimen proved absence of any serious side effects which could be relate to valproic acid toxicity "results not shown", regimen already fulfilled our requirements and for this, therapy should not be further intensified.

\section{CONCLUSION}

The proposed epi-drug combination distinctively modified the malignant transcriptome of AML blasts through inhibition of DNA hypermethylation \& histone acetylation and conferred positive prognostic impact on AML patients.

\section{AKNOWLEDGEMENT}

We thank staff of Hematological Diseases Unit, Department of Internal Medicine in Alexandria Faculty of Medicine, special thanks to Prof. Dr. Hashem Neanae; Head of department for helpful patient supervision, to Dr. Ahmad Abd EL-Rahman for patient recruitment \& to Prof. Dr. Alaa eldeen ismail abd-elmotalib Ain Shams Faculty of Medicine, for his helpful discussion. Thanks to Biochemistry Lab. \& department staff in Faculty of Science for authorizations \& providing equipments, also to Alexandria Research Institute for technical support.

\section{FOOTNOTES}

$1^{*}$ This study was approved by the Alexandria University G.S.R.A. Division no. $(537) / 4 / 7 / 20 / 2 / 1$. 
2* Valproic acid used as Depakene chrono 500 ® tab., purchased from Sanofi /Aventis; EGCG given as Green tea ${ }^{\circledR}$ tab. $1 \mathrm{gm}$ equ. to $200 \mathrm{mg}$ EGCG according to the manufacturer instructions purchased from Technomad Co. An $\mathrm{IC}_{50}$ of $\sim 20 \mu \mathrm{M}$ EGCG inhibited Dnmtl is achievable in the oral cavity after drinking green tea and perhaps in the stomach, esophagus, and intestines where there is direct contact between EGCG and the epithelial cells. The effective concentrations of EGCG $(10-50 \mu \mathrm{mol} / \mathrm{L})$ observed in studies with cell lines are 50 times higher than plasma and tissue levels of EGCG generally observed after ingestion of tea (1).A single, 200-mg dose of EGCG produces a plasma EGCG concentration of $\sim 0.1$ $\mathrm{mmol} / \mathrm{L}$. usually; the consumption of pharmaceutically prepared formulations of green tea polyphenols would produce plasma EGCG concentrations approaching $2 \mathrm{mmol} / \mathrm{L} \mathrm{(48)}$. The total daily dose ranges of EGCG used to treat cancer are generally from about $10 \mathrm{mg}$ to about $100,000 \mathrm{mg}$ according to the U. S. Patent no.6652890 (49); administered in divided doses "parenterally or orally or topically" with a preferred total daily dose from about 0.1 $\mathrm{mg}$ to about $10 \mathrm{mg} / \mathrm{kg} / \mathrm{day} "$. 3* Descriptive, inferential, and survival statistical analysis were performed using Two-Way ANOVA of Microcal Origin software [V. 8.0 SR2, 2008]. at $\mathrm{p}=0.01$ significance level. Kaplan Meier's analysis was done using [MedCalc. 7.7.4.]. Dunnett's test [KWIKSTAT WINKS SDA 6.0.] \& Kruskal-Wallis test calculated at $\alpha=0.01$ significance to determine specific pair wise differences "results not shown". 4* Assessment of some hematological prognostics in treated group followed IPSS score system. Toxicity grading performed according to NCI Common Toxicity Criteria (CTC) (version 2).

\section{ABBREVIATIONS}

HDACs / HDACi: histone deacetylases / inhibitor

HMTase: histone methyltransferase

Epigallocatechingallate: EGCG

VPA: Valproic acid

MDS: Myelodysplastic syndrome.

\section{Correspondence:}

1 Dr. Rola Mohammad Ghorab
academic738@yahoo.com

\section{REFERENCES}

Adams, R.L., Rinaldi, A., Seivwright, C., et al., Microassay for DNA methyltransferase, J. Biochem. \& Biophy. Methods, 22 (1991), (1): 19-22.

Aggerholm, A., Holm, M.S., Guldberg, P., et al., Promoter hypermethylation of p15INK4B, HIC1, CDH1, and ER is frequent in myelodysplastic syndrome and predicts poor prognosis in earlystage patients, Eur. J. Haematol, 76 (2006), (1):23-32.

Albitar, M., Angiogenesis in Acute Myeloid Leukemia and Myelodysplastic Syndrome, Acta Haematol, (200)1; 106:170-176

Berletch, J.B., Liu, C., Love, W.K., et al., Epigenetic and Genetic Mechanisms Contribute to Telomerase Inhibition by EGCG, Journal of Cell Biochemistry, 103 (2008), (2): 509-19.

Bug, G., Ritter, M., Wassmann, B., et al., Clinical trial of valproic acid and alltrans retinoic acid in patients with poorrisk acute myeloid leukemia, Cancer, 104 (2005), (12): 2717-2725.

Burnette, N.W.; Western blotting: electrophoretic transfer of proteins from sodium dodecyl sulfate polyacrylamide gel to unmodified nitrocellulose and radiographic detection with antibody and radioiodinated protein A, Analytical Biochemistry USAP, 112 (1981), (2):195-203.

Carew, J.S.; Giles, F.J. and Nawrocki, S.T. Histone deacetylase inhibitors: Mechanisms of cell death and promise in combination cancer therapy, Cancer Letters, 269 (2008), (1): 7-17.

Catalano, M.G.; Fortunati, N.; Pugliese, M., et al., Valproic Acid Induces Apoptosis and Cell Cycle Arrest in Poorly Differentiated Thyroid Cancer Cells, Journal of Clinical Endocrinology \& Metabolism 90,(2004), (3): 1383-1389.

Chen, G.; Yuan, P.X. and Jiang, Y.M., et al., Valproate robustly enhances AP-1 mediated gene expression, Brain Research. Molecular Brain Research, 64 (1999), (1): 52-58.

Choi, K-C.; Jung, M.G. and Lee, Y-H., et al., Epigallocatechin-3-Gallate, a Histone Acetyltransferase Inhibitor, Inhibits EBV-Induced B Lymphocyte Transformation via Suppression of RelA Acetylation, Cancer Research, 69 (2009) , (2): 583-592.

Chomczynski, P. and Sacchi, N. Single-step method of RNA isolation by acid guanidinium thiocyanate-phenol- 
chloroform extraction, Anal. Biochem., 162 (1987), (1): 156-9.

Chow, H.H., Cai, Y., Hakim, I.A., et al., Pharmacokinetics and safety of green tea polyphenols after multiple-dose administration of epigallocatechin gallate and polyphenon $\mathrm{E}$ in healthy individuals,Clin. Cancer Res, 9, (2003), 3312-3319.

Chuang, J.C., Yoo, C.B., Kwan, J.M., et al., Comparison of biological effects of nonnucleoside DNA methylation inhibitors versus 5-aza-2'-deoxycytidine, Molecular Cancer Therapeutics, 4 (2005), 1515-20.

Detich, N., Bovenzi, V., and Szyf, M., Valproate Induces Replicationindependent Active DNA Demethylation, J. Biol. Chem., 278 (2003), (30): 27586-27592.

Fang, M.Z., Wang, Y., Ai, N., et al., Tea polyphenol (-)-epigallocatechin-3-gallate inhibits DNA methyltransferase and reactivates methylation-silenced genes in cancer cell lines, Cancer Research, 63, (2003), 7563-7570.

Fassina, G., Venè, R., Morini, M., et al., Mechanisms of inhibition of tumor angiogenesis and vascular tumor growth by epigallocatechin-gallate, Clinical Cancer Research, 10 (2004), (14): 48654873.

Gerhauser, C., Kilmo, K., Heiss, E., et al., (2003): Mechanism-based in vitro screening of potential cancer chemopreventive agents. Mutat. Res. 523-524:163-172.

Göttlicher, M., Minucci, S., and Zhu, P., et al., Valproic acid defines a novel class of HDAC inhibitors inducing differentiation of transformed cells, EMBO J., 20 (2001), (24 ): 6969-6978.

Guo, S., Yang, S., Taylor, C., Sonenshein, G.E., Green tea polyphenol epigallocatechin-3 gallate (EGCG) affects gene expression of breast cancer cells transformed by carcinogen 7,12 dimethyibenz[a]anthracene, J.nutr, 135 (2005), (12S) 2978-2986.

Herman, J.G., Graff, J.R., Myöhänen, S., et al., Methlyation-specific PCR: A novel PCR assay for methylation status of $\mathrm{CpG}$ islands, Proc Natl Acad Sci., 93 (1996), (18): 9821-9826.

Hitomi, T., Matsuzaki, Y., Yokota, T., et al., $\mathrm{p} 15^{\mathrm{INK} 4 \mathrm{~b}}$ in HDAC inhibitor-induced growth arrest,. FEBS Lett., 554 (2003), (3):347-350.

Hodge, D.R., Cho, E., Copeland, T.D., et al., IL-6 enhances the nuclear translocation of DNA cytosine-5-methyltransferase 1
(DNMT1) via phosphorylation of the nuclear localization sequence by the AKT kinase, Cancer Genomics Proteomics. 4, (2007), (6):387-398.

Ichiyama, T., Okada, K., Lipton, J.M., et al., Sodium valproate inhibits production of TNF- $\alpha$ \& IL-6 \& activation of NF- $\mathrm{b}$, Brain research, 857 (2000), (1-2): 246251.

Kaiser, M., Zavrski, I., Sterz, J., et al., The effects of the histone deacetylase inhibitor valproic acid on cell cycle growth suppression and apoptosis in multiple myeloma, Haematologica, 91(2006), 248-251.

Kishikawa, S., Ugai, H., Murata, T., et al., Roles of histone acetylation in the Dnmt1 gene expression, Nucleic Acids Res Suppl, (2) (2002), 209-10.

Kizaki, M., Biological significance of myeloperoxidase (MPO) on green tea component, (-)-epigallocatechin-3gallate (EGCG)-induced apoptosis : its therapeutic potential for myeloid leukemia, Targeted oncology, 3 (2008), (1): 45-50.

Landriscina, M., Cassano, A., Ratto, C., et al., Quantitative analysis using ELISA of basic fibroblast growth factor and vascular endothelial growth factor in human colorectal cancer, British Journal of Cancer, 78 (1998), (6):765-770.

Lee, A.H., Fraser, M.L., Meng, X., et al., Protective effects of green tea against prostate cancer, Expert Rev Anticancer Ther, 4 (2006), 507-513.

Morré DM., and Morré DJ., Tea catechins as cancer specific proliferation inhibitors, United States Patent, 6652890, (2003), app. 09/537,211.

Renard, P., Ernest, I., Houbion, A., et al., Development of a sensitive multi-well colorimetric assay for NF- $\mathrm{b}$, Nucleaic acid research, 29 (2001), (4): E21.

Schreiber, E., Matthias, P., Muller, M., et al., Rapid detection of octamer binding proteins with 'mini-extracts', prepared from a small number of cells, Nuc.Acid Res., 17 (1989), (15): 6419.

Shankar, S., Ganapathy, S., Hingorani, S.R., et al., EGCG inhibits growth, invasion, angiogenesis \& metastasis of pancreatic cancer, Front. Biosci., 13 (2008), 440-52.

Shim, J.H., Choi, H.S., Pugliese, A., et al., (-)Epigallocatechin gallate regulates CD3mediated T-cell receptor signaling in leukemia through the inhibition of ZAP70 kinase, J.Biol.Chem, 283 (2008), (42S):28370-9. 
Shimizu, M., and Weinstein, I.B., Modulation of signal transduction by tea catechins and related phytochemicals, Mutat. Res.,591 (2005), (1-2):147-60.

Shin, H.Y., Kim, S.H., Jeong, H.J., et al., Epigallocatechin-3-gallate inhibits secretion of TNF-alpha, IL-6 and IL-8 through the attenuation of ERK and NFkappaB in HMC-1 cells, Int. Arch. Allergy Immunol, 142 (2007), (4):33544.

Sridhar, J., Akula, N., and Pattabiraman, N., Selectivity and Potency of Cyclindependent Kinase Inhibitors, AAPS J., 8 (2006), (1): E204-E221.

Stockand, J.D., Edinger, R.S., Al-Baldawi, N., et al., Isoprenylcysteine-O-carboxyl Methyltransferase Regulates Aldosterone-sensitive $\mathrm{Na}+$ Reabsorption, J.Biol.Chem, 274 (1999), (38): 2691226916.

Suganuma, M., Sueoka, E., Sueoka, N., et al., Mechanisms of cancer prevention by tea polyphenols based on inhibition of TNFlalpha expression, BioFactors, 13 (2000), (1-4): 67-72.

Sullivan, E., Reddy, A.M., Dietzmann, K., et al., Epigenetic Regulation of Tumor Necrosis Factor AlphaK. Mol. \& cell Biol, (2007), 5147-5160.

Sullivan, K.E., Reddy, A.B., Dietzmann, K., et al., Epigenetic Regulation of Tumor Necrosis Factor Alpha, Mol. \& cell Biol., 27 (2007), (14): 5147-5160.

Takiguchi, M., Achanzar, WE., Qu, W., et al., Effects of cadmium on DNA-(Cytosine5) methyltransferase activity and DNA methylation status during cadmiuminduced cellular transformation, Exp Cell Res, 286 (2003), (2): 355-365.

Teofili, I., Martini, M., Luongo, M., et al., Hypermethylation of $\mathrm{GpG}$ islands in the promoter region of $\mathrm{p} 15 \mathrm{INK} 4 \mathrm{~b}$ in acute promyelocytic leukemia represses p15INK4b expression and correlates with poor prognosis. Leukemia 17, (2003), 919-924.
Tong, X.,Yin, L., and Giardina, C., Butyrate suppresses Cox-2 activation in colon cancer cells through HDAC inhibition, Biochem.\& biophy.res.comm, 317, (2004), (2):463-71.

Tosato, G., Seamon, K.B., Goldman, N.D., et al., Monocyte-derived human B-cell growth factor identified as interferonbeta 2 (BSF-2, IL-6), Science, 239 (1988), (4839): 502-504

Tsellou, E., Troungos, C., Moschovi, M., et al., Hypermethylation of $\mathrm{CpG}$ islands in the promoter region of the p15INK4B gene in childhood acute leukaemia, Eur.J.Cancer, 41 (2005), (4): 584-9.

Weichert, W., Boehm, M., Gekeler, V., et al., High expression of RelA/p65 is associated with activation of nuclear factor-kappaB-dependent signaling in pancreatic cancer and marks a patient population with poor prognosis, Br.J.Cancer.97, (2007), (4):523-30.

Wong, I.H., Ng, M.H., Huang, D.P., et al., Aberrant p15 promoter methylation in adult and childhood acute leukemias of nearly all morphologic subtypes: potential prognostic implications, Blood, 95 (2000), (6):1942-1949.

Yamamoto, K., Arakawa, T., Ueda, N., et al., Transcriptional roles of nuclear factor NF-kB and NF-IL6 in the tumor necrosis factor a-dependent induction of cyclooxygenase-2 in MC3T3E1 cells, J.Biol.Chem, 270 (1995), (52):3131531320.

Zhou, B.P., Liao, Y., Xia, W., et al., HER2/neu induces p53 ubiquitination via Akt-mediatedMDM2 phosphorylation, Natural Cell Biology, 3 (2001), (11): 973-82. 


\section{ARABIC SUMMARY}

\section{علاج جديد لمرضى اللوكيميا النخاعية الحادة بإستخدام العقاقير الجينية يؤدى إلى تحسين نتائج إكلينيكية و جزيئية}

$$
\begin{aligned}
& \text { رولا محمد غراب ـ محمد فاروق كامل }
\end{aligned}
$$

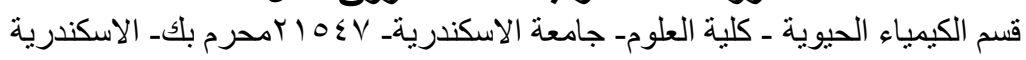

أن تثبيط الجينات بتأثير الميثيل المضافة لمحفزات الجينات المثبطة للورم وتأثنيرفوف الأستلة للهييتون

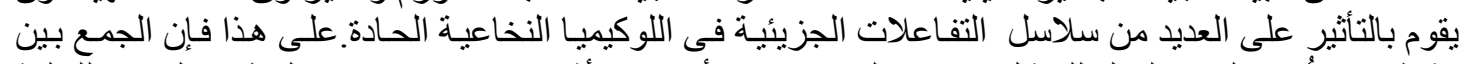

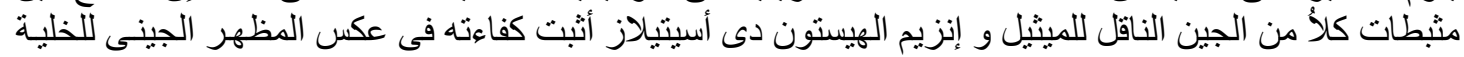

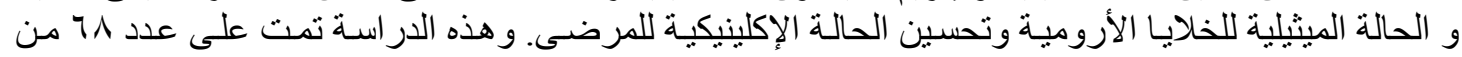

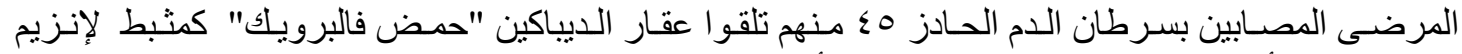

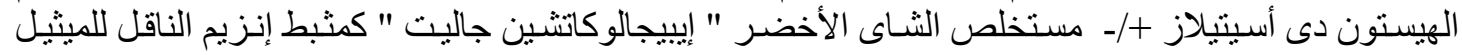

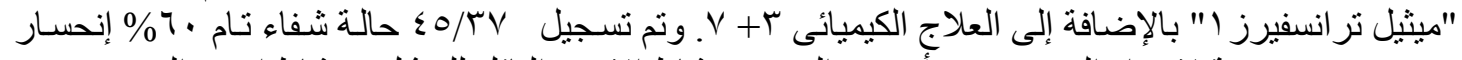

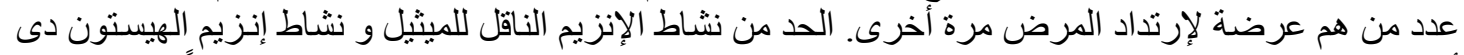

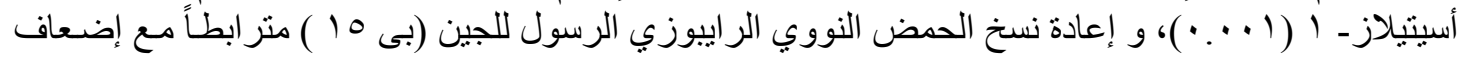

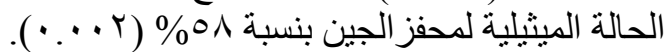

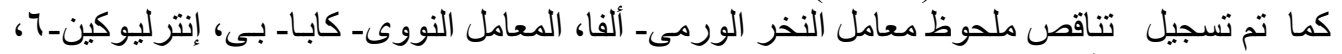

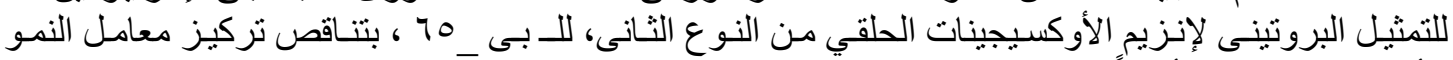

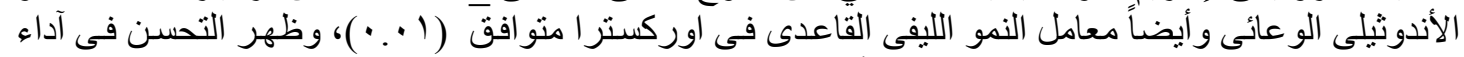

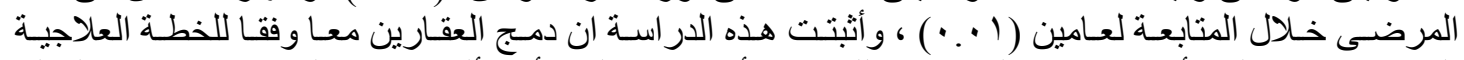

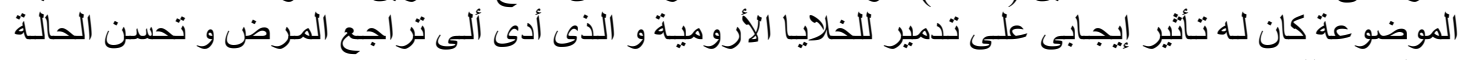
الإكلينيكية للمرضى. 